\title{
Chapter 6 \\ Effective Poyang Lake Conservation? \\ A Local Ecology View from Downstream \\ Involving Internationally Migratory Birds \\ When Trying to Buffer and Manage Water \\ from HKH with 'Modern' Concepts
}

\author{
Falk Huettmann
}

Asia offers huge wetlands, many are still 'wild' and virtually all are unique and have great international relevance, e.g. for biodiversity, climate and water management (Keddy 2010); they certainly lack a comparison with Europe and most of North America, where the majority of wetlands got massively drained as part of a government policy already for longer than 300 years (Diamond 1999). Similar policies were also applied to Asia, specifically China where irrigation was practiced for millennia (Elvin 2006). But often those policies left most wetlands 'wet'. Industrialization was not unleashed there to the same extent than in 'the west' and with more space available, and thus until recently the impacts were less serious (e.g. Elvin 2006; Harris 2008). To this very day those vast wetland landscapes usually contribute to world civilizations even (examples are found in Hungary, Shanghai-China, St. Petersburg-Russia or Great Lakes of North America). Most of those wetlands are directly fed by the waters that come from downhill (mountains). In this case here, the watersheds of Poyang Lake get fueled by the highest mountains in the world: the Hindu Kush-Himalaya (HKH).

From all of those Asian landscapes and watersheds, Poyang Lake is definitely standing out and it's easily among the top wetland landscapes in the world. Its size, renewal power and biological wealth allows for humans to make a good living, all done in a benign and somewhat sustainable fashion. For many centuries it provided an Asian culture and lifestyle central to the core of China's culture (Elvin 2006). Cities like Nanchang, Jingdezhen, Fuzhou, Yingtan and Jiujang are driven directly

Publisher's Note - Springer Nature remains neutral with regard to jurisdictional claims in published maps and institutional affiliations.

\footnotetext{
F. Huettmann $(\bowtie)$

-EWHALE lab- Institute of Arctic Biology, Biology \& Wildlife Department,

University of Alaska Fairbanks, Fairbanks, AK, USA

e-mail: fhuettmann@alaska.edu
} 


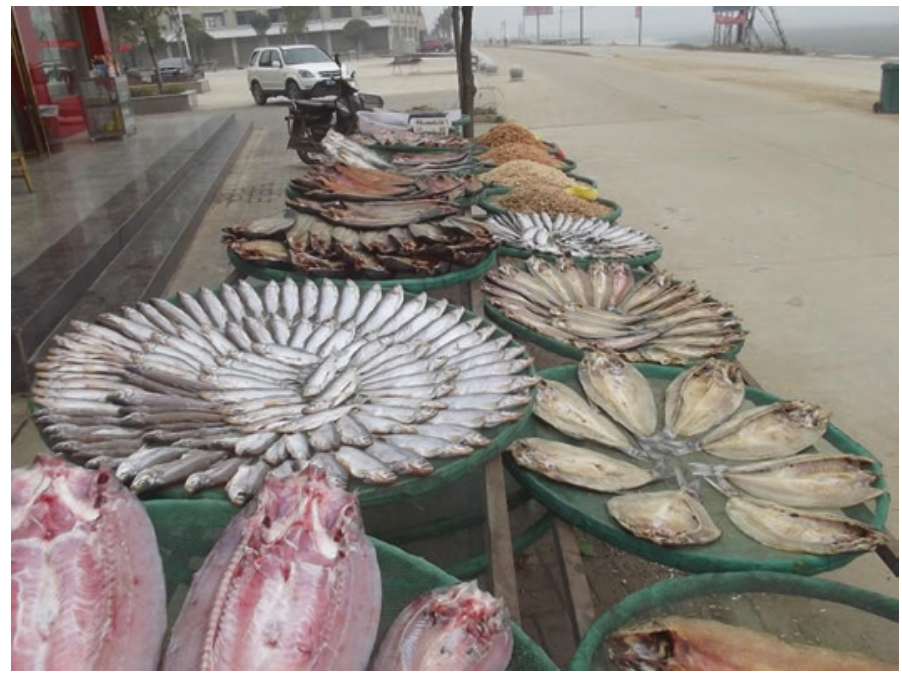

Fig. 6.1 Poyang Lake fisheries and its products offered by restaurants and street vendors

by that lake, its wealth and dynamics. Many dynasties took that wealth of this vast wetland systems and lived from it. Poyang Lake had its ups and downs over time (e.g. Elvin 2006). However, it remains a major biodiversity hotspot (Wang et al. 2007, 2017). But the environment is strongly changing and now drying, and thus its role and wealth is starting to decay (Zhang et al. 2012, 2014). Recent development plans for the area are presented (e.g. Duowen and Xueqing 2011), more are to come and all are well-known for impacts (Lai et al. 2014a). Specifically, these impacts affect the ancient waterflow and subsequently the freshwater fisheries (see Fig. 6.1), the local culture, and then also the wintering sites of arctic and asian migratory species. Those details will be elaborated in the next sections.

\subsection{Waterflow and Changes of the Poyang Lake}

Poyang Lake is primarily fed through the rivers of Gan, Xin, and Xiu which are channeled through a canal by the Yangtze river. It starts from the Tangula Mountain region, app. 5, $170 \mathrm{~m}$ high, in the Hindu Kush-Himalaya region of Qinghai, China. The Yangtze river is the longest river in Asia running downhill from the HKH region to the Yellow Sea eventually. And before its water slows down -running from the mountains - eventually it accumulates in Poyang Lake. Several other large lakes and wetland systems are also linked with Poyang Lake and its watershed acting as a natural buffer. Those lakes are Daguan Lake, Longgan Lake, Changhu Lake, Pohu Lake, Huanghu Lake and Junshan Lake for instance. Eventually, several rivers from there end up in the Yellow Sea running by the famous and ancient cities like Kaifeng and Shanghai. These cities have a large human, often global, history and legacy 


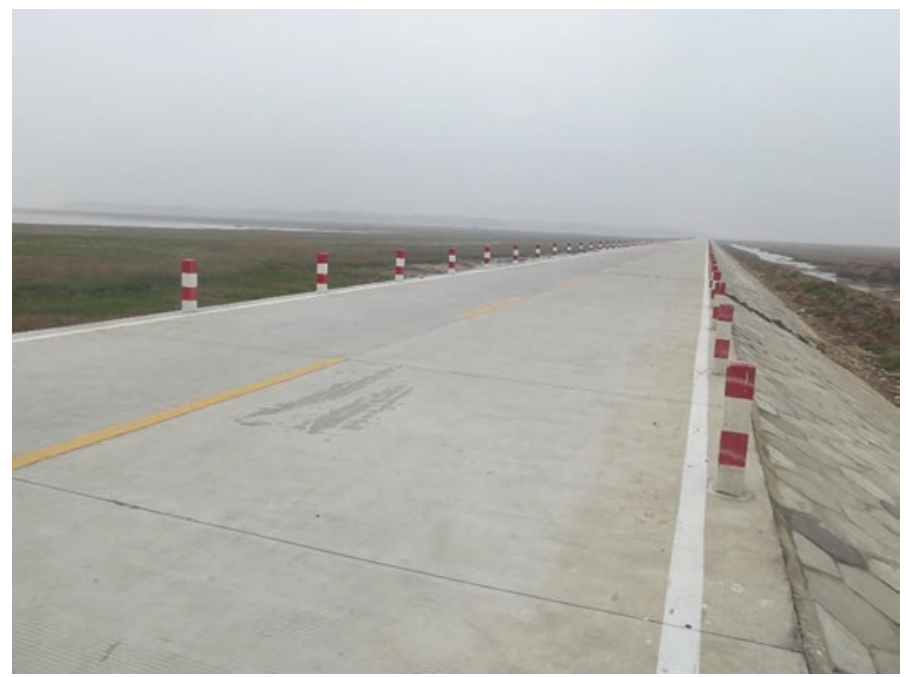

Fig. 6.2 Dykes used for a safe water management leave many impacts, including road and development facilitations. Note: this area is directly used and frequented as a wintering site by the critically endangered Siberian Crane migrating from the High Arctic

(Elvin 2006). The Yellow Sea - as a tidal mudflat system linking with the Chinese Sea - is not short of its own records but now also in big environmental troubles (MacKinnon et al. 2012).

From deep time Poyang Lake is famous for its seasons and for the associated water fluctuations (Barzen 2012). It is all part of an Asian life line that maintained parts of the global civilization easily for over four millennia (Elvin 2006). The lake is also famous for ancient naval battels, as well as for ships getting lost there for mysterious reasons and never to be found again. There are many mysteries about this lake and its inherent processes. Irrigation projects have been carried out for centuries (Fig. 6.2). To no surprise Poyang Lake plays that big role in the Asian culture, and the $\mathrm{HKH}$ region upstream is a direct driver for this watershed, including its weather (some details in Fei et al. (2016)). This is all a 'big deal' and not to be taken lightly.

\subsection{Modern Changes of Poyang Lake}

But in modern time, many changes occurred for Poyang Lake. Already upstream, the Three Gorge Dams and the newly planned dykes that are to handle the water management are a problem and they present a major item of disturbance for the wider ecosystems by now. It's part of the Anthropocene. Those issue have received an international attention and are widely discussed (Guo et al. 2012; Feng et al. 2013; Lai et al. 2014a) and for wider impacts (Wu et al. 2009). 
More complete assessments of the wider Poyang Lake situation do exist - entire research institutes are set up to tackle those issues already for decades - but those elaborations are primarily done in Chinese and can lack a western-style vetting and openly-discussed conservation view that most of the global community is usually used to and as it is commonly done for good performance. For instance, Poyang Lake awaits an assessment that is done with an Ecological Economics perspective (e.g. Czech and Daly 2004; Daly and Farley 2010; see also Czech et al. 2000; Huettmann 2014). That's because it should be emphasized that most western-style research comes from an capitalistic ideology usually involving NGOs, whereas China pursues a marxist-leninist governance scheme and tends to run a different science concept and institution. Thus, aim, culture, perceptions and outcome do differ. But where there is less difference and good agreement is in the concept that wetlands are of global relevance and provide ecological services to the global community! Climate and migratory species are a good example for that, and so is food security, water supply, waste, contamination and ecological cleansing, or the human need to have recovery areas to engage with nature (Table 6.1).

The large water system of Poyang Lake was used by local fishermen in relatively low harvests for millennia. However, during different regimes these methods and concepts have changed: It went from wilderness to an indigenous and Asian feudal system to the Chinese empires, foreign dominations, and then, an almost centurylong communistic regime, and now, a new exploitive capitalistic development focus also using computing power and remote sensing as well as globalization (Diamond 1999; Elvin 2006). Like elsewhere in the world, essentially a devastating cash

Table 6.1 Selection of roles of Poyang lake in the wider ecosystem perspective

\begin{tabular}{|c|c|c|}
\hline $\begin{array}{l}\text { Ecosystem } \\
\text { Service }\end{array}$ & Relevance & Study (selection) \\
\hline Biodiversity & Hotspot and species source & $\begin{array}{l}\text { Wang et al. (2007; for } \\
\text { invertebrates see also in } \mathrm{Wu} \\
\text { et al. 2009, Sullender et al. } \\
\text { 2016) }\end{array}$ \\
\hline Water cleaning & Major relevance for clean water & $\begin{array}{l}\text { Zhang et al. (2012) and Lai } \\
\text { et al. (2014a) }\end{array}$ \\
\hline $\begin{array}{l}\text { Microclimate } \\
\text { feedback }\end{array}$ & $\begin{array}{l}\text { Embedded in wider cycles and systems; the } \\
\text { local weather is also driven by the lakes } \\
\text { affecting farming etc. }\end{array}$ & Fei et al. (2016) \\
\hline $\begin{array}{l}\text { Food } \\
\text { production }\end{array}$ & Fisheries and farming & Huang et al. (2013) \\
\hline $\begin{array}{l}\text { Irrigation for } \\
\text { farming }\end{array}$ & Food security for millennia & Elvin (2006) \\
\hline $\begin{array}{l}\text { Migratory bird } \\
\text { habitat }\end{array}$ & $\begin{array}{l}\text { Arctic and tropical waterbirds, including } \\
\text { internationally endangered species during } \\
\text { wintering }\end{array}$ & $\begin{array}{l}\text { Rogacheva (1992) and } \\
\text { Sullender et al. }(2016)^{\mathrm{a}}\end{array}$ \\
\hline
\end{tabular}

${ }^{a}$ See also https://www.iucn.org/content/poyang-lake-wetlands-management-report, https://www. savingcranes.org/poyang-lake-report/, https://www.ramsar.org/news/poyang-lake-and-the-statusof-chinese-wetlands 
economy now rules the resource management (Fig. 6.1, Czech et al. 2004). Another major impact came simply with monofilament (plastic) nets in the 1970s creating havoc in the ecosystem, e.g. small net sizes, bycatch and unregulated poaching all happening on a dramatic scale. And like elsewhere in Asia it is known that nets are not only used under water but also on land catching there songbirds (incidentally but in large and persistent numbers). In both cases, this is an indiscriminate catch and thus very devastating, specifically when it occurs on a vast landscape-scale without relevant enforcement to stop it entrenched as a culture and somewhat institutionalized in the 'status quo'. Such catching is still ongoing to this very day (see for instance recent campaign by Audubon Society http://www.audubon. org/magazine/ may-june-2014/fighting-bird-poachers-chinas-poyang-lake). Consequently, the natural resource pays the price. Primarily, that is the freshwater fish that gets reduced, but also several endangered species are among those, and certainly the ecosystem overall and virtually all of the ecological services. The finless porpoise, a small cetacean from the Yangtze River, is already heavily reduced and could get extinct (https://www.chinadialogue. net/article/show/ single/en/839-Poyang-Lake-savingthe-finless-porpoise; Fang et al. 2006 for context). Songbirds are in generic decline in Asia, especially in China (Jiao et al. 2016; see Kamp et al. 2015 for 90\% population crashes). Another widely forgotten side-aspect are the millions of unnamed migratory waterbirds that make use of Poyang Lake as a resting and winter grounds. Simply by 'developing' Poyang Lake the wintering habitats for those species are sacrificed further, just like their food items. Such wilderness systems are on an overall and consistent decline, so are the surrounding areas, flyways and by now the atmosphere overall (Table 6.2).

But by now, not only the natural resource but the landscape itself is modified. This is due to the dykes, and the road systems, including housing, farming and tourism that is heavily encroaching further onto this ecosystem. In this context a surprising but destructive feature for outsiders might be sand mining (for details see here de Leeuw et al. 2009; Lai et al. 2014b; see also maps presented online https://thecon-versation.com/the-world-is-facing-a-global-sand-crisis-83557). Aside of generic river bed destruction sand mining is said to be a major cause for the massive decline of the finless porpoise (https://www.chinadialogue.net/article/show/single/ en/839-Poyang-Lake-saving-the-finless-porpoise). Other factors associated with those developments are the excessive use of herbicides, insecticides and pesticides (see Fig. 6.3 for examples and evidence); many other parts of the world ban such type of use of those problematic substances and in that amount. It will leave impacts on the wider food chain, certainly on the food source for many species - insects and plankton - which the spraying is to reduce. Long-term impacts are not so well known, yet but one may assume they are very serious and to be pre-cautionary is suggested (Fig. 6.4, Table 6.3).

The water levels of Poyang Lake are now dramatically in decline and the lake area shrinks accordingly (Zhang et al. 2014; Lai et al. 2014b; see also Ives 2016). Water is the essence of life and it's the very foundation of the Poyang Lake and its wider community at large. Much of this water comes from the HKH region, making the atmospheric and ocean links ('couplings'). But beyond the actual lack, and 
Table 6.2 Some charismatic migratory animal species of Poyang Lake that are relying on this ecosystem

\begin{tabular}{|c|c|c|c|}
\hline Species and status & $\begin{array}{l}\text { Usage of Poyang } \\
\text { Lake }\end{array}$ & $\begin{array}{l}\text { Origin and } \\
\text { Connectivity }\end{array}$ & Citations \\
\hline $\begin{array}{l}\text { Chinese alligator (Critically } \\
\text { endangered) }\end{array}$ & Habitat & $\begin{array}{l}\text { Yangtze River and } \\
\text { wider Poyang Lake }\end{array}$ & $\begin{array}{l}\text { Fang et al. } \\
\text { (2006). See also } 1 . \\
\text { (URL below) }\end{array}$ \\
\hline $\begin{array}{l}\text { Finless Porpoise } \\
\text { (Endangered) }\end{array}$ & Habitat & $\begin{array}{l}\text { Yangtze River and } \\
\text { wider Poyang Lake }\end{array}$ & $\begin{array}{l}\text { Fang et al. } \\
\text { (2006). See also } 2 \text {. } \\
\text { (URL below) }\end{array}$ \\
\hline \multirow[t]{2}{*}{$\begin{array}{l}\text { Siberian Crane (Critically } \\
\text { endangered) }\end{array}$} & \multirow{2}{*}{$\begin{array}{l}\text { Winter habitat for } \\
90 \% \text { of the } \\
\text { population }\end{array}$} & \multirow[t]{2}{*}{ High Arctic Russia } & $\begin{array}{l}\text { Kanai et al. (2002) } \\
\text { and Wu et al. (2009) }\end{array}$ \\
\hline & & & $\begin{array}{l}\text { See also 3.(URL } \\
\text { below) }\end{array}$ \\
\hline $\begin{array}{l}\text { Other cranes, e.g. Hooded, } \\
\text { White-naped and Common } \\
\text { cranes }\end{array}$ & Winter population & Boreal forest zone & $\begin{array}{l}\text { See also 3.(URL } \\
\text { below) }\end{array}$ \\
\hline $\begin{array}{l}\text { Oriental Storks } \\
\text { (Endangered) }\end{array}$ & $\begin{array}{l}\text { Winter habitat for } \\
\text { most of the world's } \\
\text { population }\end{array}$ & Forests & $\begin{array}{l}\text { See also 3.(URL } \\
\text { below) }\end{array}$ \\
\hline \multirow[t]{2}{*}{$\begin{array}{l}\text { Eurasian Spoonbill } \\
\text { (Conservation concern) }\end{array}$} & \multirow[t]{2}{*}{ Winter habitat } & \multirow[t]{2}{*}{$\begin{array}{l}\text { Northern reedbeds } \\
\text { and marshes }\end{array}$} & $\begin{array}{l}\text { Sullender et al. } \\
\text { (2016) }\end{array}$ \\
\hline & & & $\begin{array}{l}\text { See also 3.(URL } \\
\text { below) }\end{array}$ \\
\hline \multirow{2}{*}{$\begin{array}{l}\text { Geese (e.g. Arctic Geese } \\
\text { and Swan Geese) (Partly } \\
\text { declining) }\end{array}$} & \multirow[t]{2}{*}{ Winter habitat } & \multirow[t]{2}{*}{ High Arctic Russia } & Rogacheva (1992) \\
\hline & & & $\begin{array}{l}\text { See also 3.(URL } \\
\text { below) }\end{array}$ \\
\hline $\begin{array}{l}\text { Songbirds (Many species } \\
\text { are in a strong long-term } \\
\text { decline) }\end{array}$ & $\begin{array}{l}\text { Stop-over and winter } \\
\text { habitat }\end{array}$ & $\begin{array}{l}\text { Boreal forest and } \\
\text { tropics }\end{array}$ & Jiao et al. (2016) \\
\hline
\end{tabular}

1. http://www.iucnredlist.org/details/867/0

2. http://www.iucnredlist.org/details/41754/0

3. https://www.savingcranes.org/poyang-lake-report/

contamination of, water, and just to show how bad it has gotten, fishery bans are now also implemented and more are discussed. With that, a sustainable practice applied for millennia came to a halt.

Arguably, 'the law', or the international community did nothing really to stop it and just watches. It's the common pattern found throughout the world but it's widely ineffective (Table 6.4; see also for instance Moores 2006 for Saemangeum and Yang et al. 2011 for Bohai Bay, and MacKinnon et al. 2012 for a wider overview in that part of Asia). This is fully in-line with the status of most migratory birds from the Arctic (Huettmann 2012) and for Asia (Jiao et al. 2016; MacKinnon et al. 2012 for habitats). It also follows the generic pattern of climate change, which is plagued for decades by inefficiency and failure for progress. 
(a)

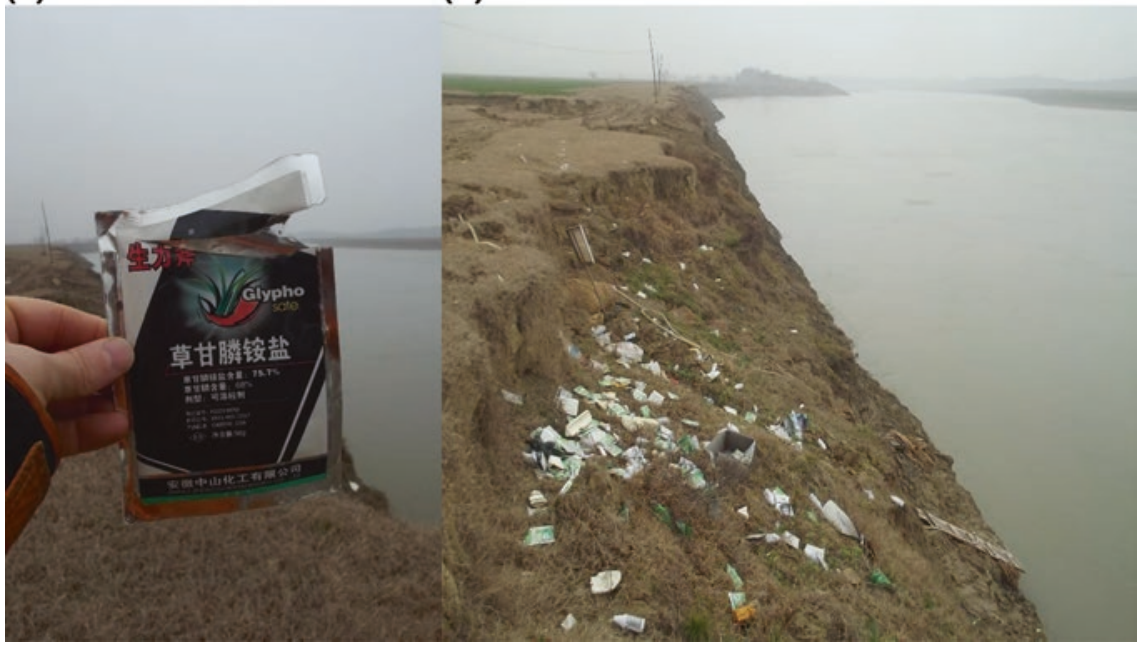

Fig. 6.3 Herbicide products are widely used in Asia (a); left-overs of herbicide products disposed at a river bank near a road (b)

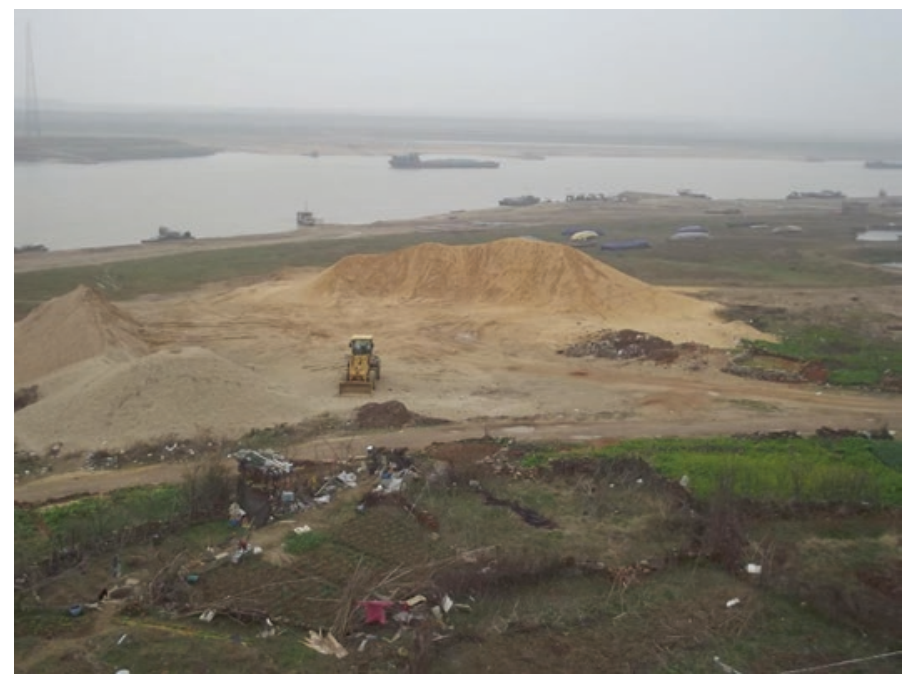

Fig. 6.4 Sand Mining as a devastating industry in the wider HKH region (Note the strong shipping traffic and the waste in this watershed of international relevance) 
Table 6.3 Selected list of features that are known to be intrusive and destructive to Poyang Lake (see also Keddy 2010)

\begin{tabular}{|c|c|c|}
\hline $\begin{array}{l}\text { Destructive } \\
\text { Feature }\end{array}$ & Impact & Comment \\
\hline Irrigation & $\begin{array}{l}\text { Water drainage out of } \\
\text { the lake; canals }\end{array}$ & $\begin{array}{l}\text { Irrigation and water deviation has been ongoing for } \\
\text { millennia in Poyang Lake. However, modern } \\
\text { large-scale technology assisted systems for } \\
\text { commercial and industrial applications are not } \\
\text { sustainable. }\end{array}$ \\
\hline Dykes & $\begin{array}{l}\text { Large changes of the } \\
\text { landscape and water } \\
\text { flow dynamics }\end{array}$ & $\begin{array}{l}\text { Major dykes have been built in the region, upstream } \\
\text { and downstream. }\end{array}$ \\
\hline Poaching & $\begin{array}{l}\text { Comes in many shapes } \\
\text { and forms, e.g. illegal } \\
\text { fisheries, bird } \\
\text { catching, and } \\
\text { unapproved hunting }\end{array}$ & $\begin{array}{l}\text { It is easy to witness many cases of illegal mist nets } \\
\text { to catch passerines etc. }\end{array}$ \\
\hline $\begin{array}{l}\text { Three Gorges } \\
\text { Dam }\end{array}$ & $\begin{array}{l}\text { Change of water flow } \\
\text { and man-made }\end{array}$ & $\begin{array}{l}\text { One of the largest hydro dams in the world, widely } \\
\text { debated for environmental impacts for over a } \\
\text { decade. As per definition any dam that fully blocks } \\
\text { waterflows is destructive. Same can be said for } \\
\text { virtually all mega projects and for gigantomania. } \\
\text { Many earlier dams now get eradicated in other parts } \\
\text { of the world. }\end{array}$ \\
\hline Tourism & Tourism consumption & $\begin{array}{l}\text { Requires tourism infrastructure and a vast foot print } \\
\text { beyond 'just' Poyang Lake. }\end{array}$ \\
\hline Fishing & $\begin{array}{l}\text { Not really based on } \\
\text { enforceable } \\
\text { sustainable quotas }\end{array}$ & A large freshwater fish harvest and resource. \\
\hline Urbanization & $\begin{array}{l}\text { Increasing on the } \\
\text { entire landscape, e.g. } \\
\text { Duowen and Xueqing } \\
\text { (2011) }\end{array}$ & A global pattern, the Anthropocene. \\
\hline Sand mining & $\begin{array}{l}\text { Serious problem and } \\
\text { not well managed (de } \\
\text { Leeuw et al. 2009) }\end{array}$ & $\begin{array}{l}\text { A global demand, related to economic growth } \\
\text { promotion. }\end{array}$ \\
\hline $\begin{array}{l}\text { Intense use of } \\
\text { herbicides, } \\
\text { pesticides and } \\
\text { insecticides }\end{array}$ & $\begin{array}{l}\text { Applied in support of } \\
\text { tropical farming }\end{array}$ & $\begin{array}{l}\text { A generic problem in Asia and widely left } \\
\text { unmanaged }\end{array}$ \\
\hline Diseases & Spreading of diseases & $\begin{array}{l}\text { Caused for instance by farming of cattle (Guo et al. } \\
\text { 2001) or poultry (Herrick et al. 2013). }\end{array}$ \\
\hline
\end{tabular}

The recent Corona Virus Pandemic started and spread from Wuhan city, not too far away from Poyang Lake 
Table 6.4 International laws that apply directly or indirectly to Poyang Lake and its bird species

\begin{tabular}{|c|c|c|}
\hline Law & Species affected & Efficiency \\
\hline $\begin{array}{l}\text { Bonn Convention } \\
\text { (Convention of } \\
\text { Migratory Species } \\
\text { CMS; 1979) }\end{array}$ & $\begin{array}{l}\text { Siberian crane, } \\
\text { geese, songbirds }\end{array}$ & $\begin{array}{l}\text { Low (has no relevant budget nor enforcement; does } \\
\text { not address habitat issues and as a concept is } \\
\text { widely outdated by now; see also review in } \\
\text { Huettmann et al. 2011) }\end{array}$ \\
\hline $\begin{array}{l}\text { Migratory Bird Act } \\
\text { MBA } 1916 \text { (and 1970s } \\
\text { extended) }\end{array}$ & $\begin{array}{l}\text { Cranes, } \\
\text { waterfowl }\end{array}$ & $\begin{array}{l}\text { Low (has no relevant budget nor enforcement; } \\
\text { conceptually outdated by now; see also review in } \\
\text { Huettmann et al. 2011) }\end{array}$ \\
\hline $\begin{array}{l}\text { Best Professional } \\
\text { Practice, e.g. } \\
\text { Conservation of } \\
\text { Biodiversity } \\
\text { Conservation (Rio } \\
\text { Convention) }\end{array}$ & $\begin{array}{l}\text { Biodiversity } \\
\text { Data sharing }\end{array}$ & $\begin{array}{l}\text { Low (various legal variations and policies stand in a } \\
\text { way of a meaningful implementation; see for } \\
\text { instance Mace et al. } 2010 \text { for status) }\end{array}$ \\
\hline $\begin{array}{l}\text { Crane Treaty and } \\
\text { Special Agreements } \\
\text { (e.g. in MBA and } \\
\text { CMS) }\end{array}$ & Crane & $\begin{array}{l}\text { Low (has a high perception but no relevant budget } \\
\text { nor enforcement or performance assessment for } \\
\text { outcome) }\end{array}$ \\
\hline IUCN & $\begin{array}{l}\text { Endangered } \\
\text { species, e.g. ibis, } \\
\text { cranes and } \\
\text { porpoise }\end{array}$ & $\begin{array}{l}\text { Medium (Political species lists that lack bias, } \\
\text { mandatory habitat and atmospheric protection) }\end{array}$ \\
\hline $\begin{array}{l}\text { Australasian wetland } \\
\text { agreement }\end{array}$ & Shorebirds & $\begin{array}{l}\text { Low (has no relevant budget nor enforcement or } \\
\text { track record; hardly a reporting) }\end{array}$ \\
\hline $\begin{array}{l}\text { RAMSAR convention } \\
\text { (1971) }\end{array}$ & $\begin{array}{l}\text { Waterbird } \\
\text { species, namely } \\
\text { ducks }\end{array}$ & $\begin{array}{l}\text { Low (has no relevant budget nor enforcement and } \\
\text { allows for many counterproductive activities in } \\
\text { RAMSAR sites; widely outdated concept; see also } \\
\text { review in Huettmann et al. } 2011 \mathrm{and}^{\mathrm{a}} \text { ) }\end{array}$ \\
\hline $\begin{array}{l}\text { Science (carried out } \\
\text { worldwide) }\end{array}$ & $\begin{array}{l}\text { Any species and } \\
\text { ecosystem } \\
\text { aspects }\end{array}$ & $\begin{array}{l}\text { Medium (thus far, science is not really geared } \\
\text { towards conservation. Lack of track record can be } \\
\text { seen in Mace et al. 2010) }\end{array}$ \\
\hline CITES & $\begin{array}{l}\text { Many } \\
\text { endangered } \\
\text { species }\end{array}$ & $\begin{array}{l}\text { CITES is designed to facilitate trade, not to halt it. } \\
\text { It's certainly not a conservation measure and it has } \\
\text { not worked well either way. Many CITES } \\
\text { violations are found in Asia and its borders, often } \\
\text { related to China and Globalization. }\end{array}$ \\
\hline
\end{tabular}

ahttps://www.ramsar.org/news/poyang-lake-and-the-status-of-chinese-wetlands

\subsection{A Relevant Future in the Anthropocene for Poyang Lake as We Know It}

So where is Poyang Lake heading? Arguably, Poyang Lake is not turning back into wilderness, or into its early status, any time soon, e.g. Fig. 6.5 for culturally entrenched and government-supported practices. Just too many development trends speak against it (Ma et al. 2009; Duowen and Xueqing 2011; Table 6.5). Sullender et al. (2016) stated already: 


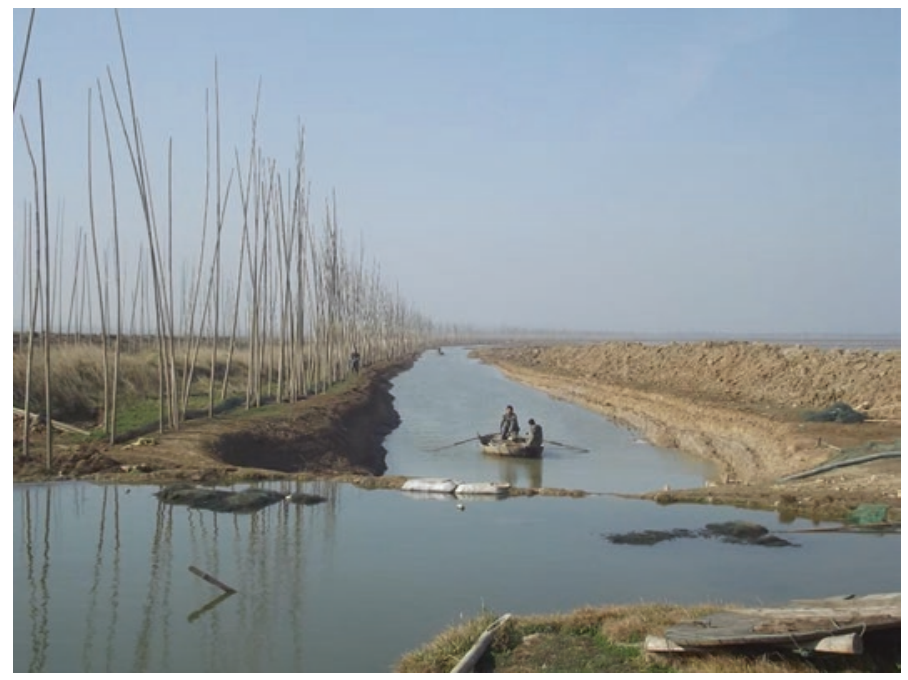

Fig. 6.5 Fishing gear set up at a channel for catches during changed water levels. Incidental bycatch, including for birds cannot be excluded

Table 6.5 Some future developments that can be expected for the Poyang Lake ecosystem

\begin{tabular}{l|l|l|l}
\hline $\begin{array}{l}\text { Poyang Lake future } \\
\text { feature }\end{array}$ & Scale & Justification for trend & Impact \\
\hline Climate change & $\begin{array}{l}\text { Global, } \\
\text { national } \\
\text { and local }\end{array}$ & Warming & $\begin{array}{l}\text { Drying and water loss; lack of } \\
\text { snow pack and glaciers in the } \\
\text { HKH result into less water } \\
\text { running downstream }\end{array}$ \\
\hline Development & Local & $\begin{array}{l}\text { Consumption of } \\
\text { resources projected }\end{array}$ & Resource overuse and loss \\
\hline $\begin{array}{l}\text { Upstream Dams } \\
\text { (e.g. Three Gorges } \\
\text { Damn) }\end{array}$ & National & $\begin{array}{l}\text { Water flow and natural } \\
\text { processes got halted and } \\
\text { 'managed' }\end{array}$ & Water dynamics are interfered \\
\hline $\begin{array}{l}\text { Human population } \\
\text { increase }\end{array}$ & Global & $\begin{array}{l}\text { Human population } \\
\text { growth }\end{array}$ & Consumption increases \\
\hline Human waste & $\begin{array}{l}\text { Global, } \\
\text { national } \\
\text { and local }\end{array}$ & $\begin{array}{l}\text { Global waste travels, } \\
\text { national waste travels, } \\
\text { local waste }\end{array}$ & Spoilage and pollution increases \\
\hline Contamination & $\begin{array}{l}\text { Global, } \\
\text { national } \\
\text { and local }\end{array}$ & $\begin{array}{l}\text { Industrialization and } \\
\text { associated air pollution } \\
\text { on the rise }\end{array}$ & $\begin{array}{l}\text { Increase resulting into health and } \\
\text { death hazards }\end{array}$ \\
\hline
\end{tabular}

Human-caused alterations to this system threaten to compromise the long-term viability of these bird populations due to the role of water in driving habitat suitability.

A synthesis view leaves no other forecast than one of wider destruction and ongoing decay. It matches many other environmental trends in the region, e.g. MacKinnon et al. (2012) for the Yellow Sea or even Liu et al. (2001) for Giant 
Table 6.6 Famous examples of massive wetland declines and losses in the world with comparable features than Poyang Lake (see also Reissner 1993 and Keddy 2010)

\begin{tabular}{|c|c|c|c|}
\hline $\begin{array}{l}\text { Wetland } \\
\text { name }\end{array}$ & Country & Process & Status \\
\hline Aral lake & $\begin{array}{l}\text { Former } \\
\text { Soviet } \\
\text { Union }\end{array}$ & $\begin{array}{l}\text { Aggressive irrigation; } \\
\text { drying }\end{array}$ & Widely destroyed, desertification ongoing \\
\hline $\begin{array}{l}\text { Elbe river } \\
\text { riparian } \\
\text { zone and } \\
\text { estuary }\end{array}$ & Germany & $\begin{array}{l}\text { Urbanization of landscape } \\
\text { and watershed, } \\
\text { eradication of riparian } \\
\text { forests }\end{array}$ & $\begin{array}{l}\text { Riparian gallery forests widely } \\
\text { disappeared, wetlands and buffer systems } \\
\text { widely gone, estuaries are developed for } \\
\text { intense shipping, fisheries and even } \\
\text { (industrial) waste disposal }\end{array}$ \\
\hline $\begin{array}{l}\text { Colorado } \\
\text { river }\end{array}$ & $\begin{array}{l}\text { Mexico } \\
\text { and USA }\end{array}$ & $\begin{array}{l}\text { One of the world's most } \\
\text { controlled and litigated } \\
\text { rivers, hydrodams, } \\
\text { farming etc }\end{array}$ & $\begin{array}{l}\text { Ran dry; Baja California in Mexico lacks } \\
\text { inflow and initial ecosystem status } \\
\text { decays. Indigenous people affected; } \\
\text { major farming area in the US affected }\end{array}$ \\
\hline $\begin{array}{l}\text { Eastern } \\
\text { Canada } \\
\text { wetlands }\end{array}$ & Canada & Urbanization of landscape & $\begin{array}{l}\text { Most wetlands are dramatically lost, duck } \\
\text { species become reduced and endangered }\end{array}$ \\
\hline $\begin{array}{l}\text { Wetlands of } \\
\text { California }\end{array}$ & USA & Urbanization of landscape & $\begin{array}{l}\text { App. } 90 \% \text { of wetlands lost, duck } \\
\text { populations become reduced and } \\
\text { endangered }\end{array}$ \\
\hline $\begin{array}{l}\text { Reed bed } \\
\text { swamps }\end{array}$ & Hungary & Irrigation & $\begin{array}{l}\text { App. } 80 \% \text { of all reed beds in Hungary are } \\
\text { lost during the last } 400 \text { years, } \\
\text { specifically under royal and absolutarian } \\
\text { governance }\end{array}$ \\
\hline $\begin{array}{l}\text { Riparian } \\
\text { forests }\end{array}$ & EU & $\begin{array}{l}\text { Modern water } \\
\text { management related to } \\
\text { urbanization and } \\
\text { industrialization }\end{array}$ & $\begin{array}{l}\text { Most riparian forests are by now } \\
\text { endangered; the vast majority was } \\
\text { removed creating major problems with } \\
\text { flooding due to missed buffering and } \\
\text { cleaning capacities in the watersheds. } \\
\text { Famous cases are found in rivers of the } \\
\text { Danube, Donau and Rhine }\end{array}$ \\
\hline
\end{tabular}

Panda habitat. It is difficult to assume that Poyang Lake will not follow what other wetlands in the world have already experienced in times of a dominating western globalization (Table 6.6). Again, this is for one of THE major landscapes and wetlands in the Chinese and Asian history and with a global civilization legacy. Entire bird flyways rely on this wetland system. But with many development initiatives ongoing 'full steam', it will simply be 'hit' further while everybody watches it and until it reaches a point of no return...like we all have seen with most other wetlands and wilderness areas we are aware of (see Fig. 6.6, Tables 6.5 and 6.6).

It is clear that without relevant changes Poyang Lake, as we know it, as an undisturbed habitat and wilderness landscape with international relevance for a benign human society will disappear soon or later (Czech et al. 2004), and so will its' species, often on an international scale. The affiliated culture is equally in transition. Smaller enforcement of compliance might look and sound impressive but hardly can fix the problems anymore. Perhaps the destruction can be halted...in 100 years 
(a)

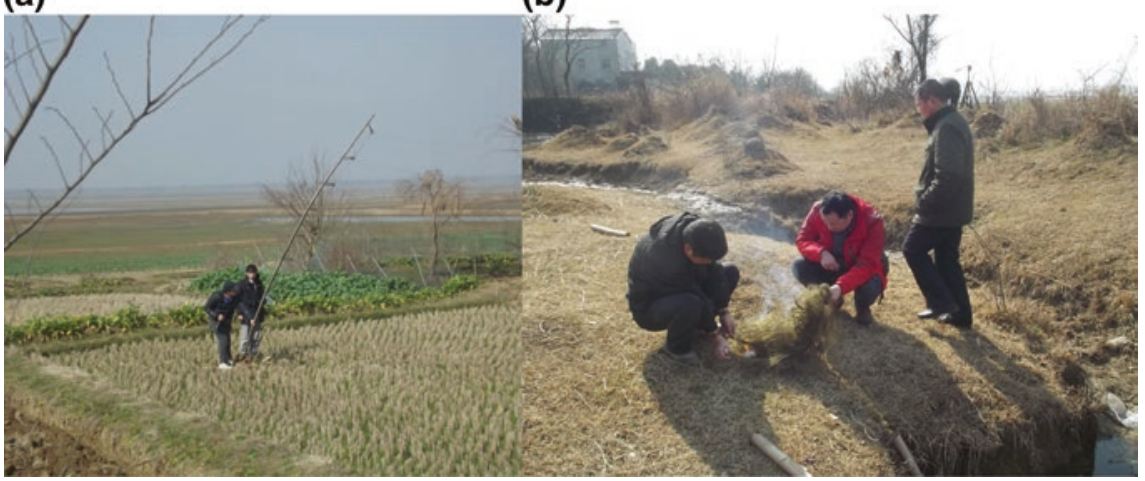

Fig. 6.6 Taking down illegal mistnets that can catch songbirds (a). Confiscation and burning of confiscated mistnets (b)

or more and some base features might remain by then. But even if local processes can get under control, the destructions upstream in the HKH region must also be addressed, namely globalization, dams, human expansion and climate change resulting into water loss, massive glacier melt and warming. And judged by the consistent but ongoing failures of climate agreement and COP meetings, and the dominance of neoliberal mind sets on global governance (e.g. Huettmann 2012, 2014) the real-world outlook to stop those processes seems to be slim for the next 100 years or so. This will all be very costly too (Wang et al. 2013). It's part of a wider western template of nature destruction (Czech et al. 2004). We shall see then what will remain under such global governance. Hope and spirituality appears like some of the best companions we have left thus far unless reason is allowed to act again in a good way.

\section{References}

Barzen J (2012) Studying and understanding wetland dynamics. In: Li F, Liu G, Wu J, Zeng N, Harris J, Jin J (eds) Ecological study of wetlands and waterbirds at Poyang Lake. Popular Science Press, Beijing, pp 256-266

Czech B, Daly H (2004) The steady state economy: what it is, entails, and connotes. Wildl Soc Bull 32:598-605

Czech B, Krausman PR, Devers PK (2000) Economic associations among causes of species endangerment in the United States. Bioscience 50:593-601

Czech B, Angermeier P, Daly H, Pister P, Hughes R (2004) Fish conservation, sustainable fisheries, and economic growth: no more fish stories. Fisheries 29:36-37

Daly H, Farley J (2010) Ecological economics. Principles and applications, 2nd edn. Island Press, New York

de Leeuw J, Shankman D, Wu G, de Boer WF, Burnham J, He O, Yésou H, Xiao J (2009) Strategic assessment of the magnitude and impacts of sand mining in Poyang Lake, China. Reg Environ Chang 10:95-102 
Diamond J (1999) Guns, germs and steel. The Fate of human societies. W.W. Norton and Company, New York

Duowen D, Xueqing T (2011) Numerical simulation of the effects of the urbanization on the Poyang wetland. In: Potter KW, Frevert DK (eds) Watershed management 2010. American Society of Civil Engineers, Reston, p 444

Elvin M (2006) The retreat of the elephants: An environmental history of China. Yale University Press, New Haven

Fei X, Liu Z, Si Y (2016) Local temperature and El Niño Southern Oscillation influence migration phenology of East Asian migratory waterbirds wintering in Poyang, China. Integrat Zool 12:303-317

Fang J, Wang Z, Zhao S, Li Y, Tang Z, Yu D, Ni L, Liu H, Xie P, Da L et al (2006) Biodiversity changes in the lakes of the central Yangtze. Front Ecol Environ 4:369-377

Feng L, Hu C, Chen X, Zhao X (2013) Dramatic inundation changes of China's two largest freshwater lakes linked to the Three Gorges Dam. Environ Sci Technol 47:9628-9634

Guo JG, Ross AG, Lin DD, Williams GM, Chen HG, Li Y, Davis GM, Feng Z, McManus DP, Sleigh AC (2001) A baseline study on the importance of bovines for human Schistosoma japonicum infection around Poyang Lake, China. Am J Trop Med Hyg 65:272-278. https://doi. org/10.4269/ajtmh.2001.65.272

Guo H, Q H, Zhang Q, Feng S (2012) Impacts of the Three Gorges Dam on Yangtze River flow and river interaction with Poyang Lake, China: 2003-2008. J Hydrol 416-417:19-27

Harris R (2008) Wildlife conservation in Western China: preserving the habitat of China's wild west. M.E. Sharpe, New York

Herrick KA, Huettmann F, Lindgren MA (2013) A global model of avian influenza prediction in wild birds: the importance of northern regions. Vet Res 44(1):42. https://doi. org/10.1186/1297-9716-44-42

Huang LL, Wu ZQ, Li JH (2013) Fish fauna, biogeography and conservation of freshwater fish in Poyang Lake Basin, China. Environ Biol Fish 96:1229-1243

Huettmann F (2012) Protection of the three poles. Springer, New York

Huettmann F (2014) Economic growth and wildlife conservation in the North Pacific Rim. Chapter 4. In: Gates E, Trauger D (eds) Peak oil, economic growth, and wildlife conservation. Island Press, Washington, DC, pp 133-156

Huettmann F, Yu Artukhin OG, Humphries G (2011) Predictions of 27 Arctic pelagic seabird distributions using public environmental variables, assessed with colony data: a first digital IPY and GBIF open access synthesis platform. Mar Biodivers 41:141-179. https://doi.org/10.1007/ s12526-011-0083-2

Ives M (2016). As China's largest freshwater Lake Shrinks, a solution faces criticism. New York Times. Retrieved 29 December 2016

Jiao S, Huettmann F, Guoc Y, Li X, Ouyang Y (2016) Advanced long-term bird banding and climate data mining in spring confirm passerine population declines for the Northeast ChineseRussian flyway. Glob Planet Change. https://doi.org/10.1016/j.gloplacha.2016.06.015

Kamp J, Oppel S, Ananin A, Durnev YA, Gashev SN, Hölzel N, Mishchenko AL, Pessa J, Smirenski SM, Strelnikov EG, Timonen S, Wolanska K, Chan S (2015) Global population collapse in a superabundant migratory bird and illegal trapping in China. Conserv Biol 29:1684-1694. https://doi.org/10.1111/cobi.12537

Kanai Y, Ueta M, Germogenov N, Nagendran M, Mita N, Higuchi H (2002) Migration routes and important resting areas of Siberian cranes (Grus leucogeranus) between northeastern Siberia and China as revealed by satellite tracking. Biol Conserv 106:339-346

Keddy P (2010) Wetland ecology: principles and conservation. Cambridge University, Cambridge

Lai X, Liang Q, Jiang J, Huang Q (2014a) Impoundment effects of the Three Gorges Dam on flow regimes in two of China's largest freshwater lakes. Water Resour Manag 28:5111-5124

Lai X, Shankman D, Huber C, Yesou H, Huang Q, Jiang J (2014b) Sand mining and increasing Poyang Lake's discharge ability: a reassessment of causes for lake decline in China. J Hydrol 519:1698-1706 
Liu J, Linderman M, Ouyang Z, An L, Yang J, Zhang H (2001) Ecological degradation in protected areas: the case of Wolong Nature Reserve for giant pandas. Science 292:98-101

Ma Z, Wang Y, Gan X, Li B, Cai Y, Chen J (2009) Waterbird population changes in the wetlands at Chongming Dongtan in the Yangtze River estuary, China. Environ Manag 43:1187-1200

Mace G, Cramer W, Díaz S, Faith DP, Larigauderie A, Le Prestre P, Palmer M, Perrings C, Scholes RJ, Walpole M, Walther BA, Watson JEM, Mooney HA (2010) Biodiversity targets after 2010. Opin Environ Sustain 2:3-8

MacKinnon J, Verkuil YI, Murray N (2012) IUCN situation analysis on East and Southeast Asian intertidal habitats, with particular reference to the Yellow Sea (including the Bohai Sea). Occasional Paper of the IUCN Species Survival Commission No. 47. IUCN, Gland/Cambridge

Moores N (2006) South Korea's shorebirds: a review of abundance, distribution, threats and conservation status. Stilt 50:62-72

Reissner M (1993) Cadillac desert: the American west and its disappearing water. Penguin Books, New York

Rogacheva H (1992) The birds of central Siberia. Husum Druck- und Verlagsgesellschaft, Husum

Sullender BK, Barzen J, Silbernagel J (2016) Foraging success and habitat selection of the Eurasian spoonbill (Platalea leucorodia) at Poyang Lake, China. Waterbirds 39:356-364

Wang HZ, Xu QQ, Cui YD, Liang YL (2007) Macrozoobenthic community of Poyang Lake, the largest freshwater lake in China, in the Yangtze floodplain. Limnology 8:65-71

Wang Y, Jia Y, Guan LEI, Lu CAI, Lei G, Wen LI, Liu G (2013) Optimising hydrological conditions to sustain wintering waterbird populations in Poyang Lake National Natural Reserve: implications for dam operations. Freshwat Biol 58:2366-2379

Wang W, Fraser JD, Chen J (2017) Wintering waterbirds in the middle and lower Yangtze River floodplain: changes in abundance and distribution. Bird Conserv Int 27:167-186

Wu G, Leeuw J, Skidmore AK, Prins HHT, Best EPH, Liu Y (2009) Will the Three Gorges Dam affect the underwater light climate of Vallisneria spiralis L. and food habitat of Siberian Crane in Poyang Lake? Hydrobiologia 623:213-222

Yang H, Chen B, Barter M, Piersma T, Zhou C, Li F, Zhang Z (2011) Impacts of tidal land reclamation in Bohai Bay, China: ongoing losses of critical Yellow Sea waterbird staging and wintering sites. Bird Conserv Int 21(3):241-259. https://doi.org/10.1017/S0959270911000086

Zhang L, Yin J, Jiang Y, Wang H (2012) Relationship between the hydrological conditions and the distribution of vegetation communities within the Poyang Lake National Nature Reserve, China. Ecol Inf 11:65-75

Zhang Q, Ye X, Werner AD, Li Y, Yao J, Li X, Xu C (2014) An investigation of enhanced recessions in Poyang Lake: comparison of Yangtze River and local catchment impacts. J Hydrol $517: 425-434$ 